\title{
INVESTIGATION OF THE GEOMETRICAL ACCURACY AND THICKNESS DISTRIBUTION USING 3D LASER SCANNING OF AA2024-T3 SHEETS FORMED BY SPIF
}

\author{
PREISKAVA GEOMETRIJSKE NATANČNOSTI IN RAZPOREDITEV \\ DEBELINE S TRIDIMENZIONALNIM LASERSKIM SKENIRANJEM \\ PLOČEVINE IZ AA2024-T3, PREOBLIKOVANE S STOPNJUJOČIM \\ PREOBLIKOVANJEM KOVINE
}

\author{
Halil Bayram,2, Nurullah Sinan Köksal ${ }^{3}$ \\ ${ }^{1}$ Uludağ University, Department of Automotive Engineering, Bursa, Turkey \\ ${ }^{2}$ Amasya University, Department of Automotive Engineering, Amasya, Turkey \\ ${ }^{3}$ Celal Bayar University, Department of Mechanical Engineering, Manisa, Turkey \\ halilbayram@uludag.edu.tr \\ Prejem rokopisa - received: 2015-09-16; sprejem za objavo - accepted for publication: 2015-12-16
}

doi:10.17222/mit.2015.296

\begin{abstract}
Incremental sheet forming (ISF) is developed in order to meet the increasing demand for sheet metal forming and because it is a more economical method. First of all, this method gains attention become it is a die-less method. Furthermore, process flexibility and higher formability are other advantages of this method. In this study, AA2024-T3 sheets with a determined geometry and parameters were formed using the ISF method. Among the forming process parameters, tool path, step size and lubrication parameters were changed. The tool diameter, feed rate, spindle speed, angle of the wall and the tool coating parameters were kept constant. The thickness distributions and geometrical accuracy of the processed samples with the three-dimensional laser scanning method were examined accurately. It is clear from the results that the tool path that spirals and always keeps in touch is more successful than the tool path that makes it an incremental process. ISF is preferable to die production for limited production runs because it is more economic and the processing time is short.

Keywords: incremental sheet forming, single point incremental sheet forming, aluminum alloy AA2024, laser scanning
\end{abstract}

Stopnjujoče preoblikovanje pločevine (angl. ISF) je bilo razvito z namenom zadovoljiti povpraševanje po različnem preoblikovanju pločevine na bolj ekonomičen način. Ta metoda vzbuja pozornost, ker gre za metodo brez orodja. Drugi dve prednosti te metode sta: fleksibilnost procesa in večja preoblikovalnost. V pričujoči študiji je bila pločevina iz AA2024-T3 preoblikovana $\mathrm{z}$ določeno geometrijo in parametri z uporabo metode ISF. Med postopkom preoblikovanja so bili spreminjani procesni parametri, kot je pot orodja, velikost koraka in parametri mazanja. Premer orodja, hitrost podajanja, hitrost vrtenja, naklon stene in parametri prekritja orodja, so bili konstantni. Razporeditev debelin in geometrijska natančnost izdelanih vzorcev so bili natančno preiskani s tridimenzionalnim laserskim skeniranjem. Rezultati so pokazali, da sta spiralna pot orodja in stalen stik bolj uspešna od poti orodja, ki dela postopoma. Pokazalo se je tudi, da je pri omejeni količini postopek ISF relativno bolj ekonomičen kot postopek $z$ orodjem in tudi čas izdelave je krajši

Ključne besede: stopnjujoče preoblikovanje pločevine, enotočkovno stopnjujoče preoblikovanje pločevine, aluminijeva zlitina AA2024, lasersko skeniranje

\section{INTRODUCTION}

Incremental sheet forming (ISF), one of the new production procedures, is developed to form sheet metal without using die. This method has advantages of process flexibility, product independent tooling and higher formability. So, it aims to decrease both the prototyping time and the set-up costs of forming, especially for a small number of pieces. However, traditional sheet metal forming methods are too much dependent on the number of parts because of the time and cost. Especially in productions having a large number of products, these methods are preferred since the cost will be reduced for each part. ${ }^{1-4}$ The production with ISF, which is also defined as die-less forming for limited parts suitable for the usage area is preferred..$^{5}$ In sheet metal production, factors such as the time, die and prototype costs become disadvantages for limited production.

It is essential in forming to keep the necessary strength minimum depending on the size, geometry and time of production and to form without any damage. Particularly in the part production special for the person and the place, quick and suitable solutions are found by using three-dimensional laser scanning. ${ }^{6}$

ISF can be applied to the specially designed machines and many computer numerical control (CNC) milling stands providing the opportunity of manufacturing. In addition, this method is categorized as singlepoint incremental sheet forming (SPIF) and two-point incremental sheet forming (TPIF). SPIF is the simplest way as a system. ${ }^{4,7}$ They are named positive forming and negative forming, respectively. Whereas in the two-point incremental sheet forming, the tool starts to form from 


\section{MATERIALI IN TEHNOLOGIJE/MATERIALS AND TECHNOLOGY (1967-2017) - 50 LET/50 YEARS}

\section{H. BAYRAM, N. S. KÖKSAL: INVESTIGATION OF THE GEOMETRICAL ACCURACY AND THICKNESS ...}

the center, it forms through the center in the single-point incremental sheet forming. ${ }^{8}$

The performance of the forming process is related to the geometry of tools. Hemisphere and ball forms are preferred in tools and their sizes are determined according to the given geometry. The head diameters of tools starts from $6 \mathrm{~mm}$ and can be up to $100 \mathrm{~mm}$ for large parts. The selection of the tool diameter is determined by looking at the lowest concave of the desired geometry. Besides, coating can be applied to tools in order to reduce the friction and prolong the life of the tool. ${ }^{8,9}$

There is no standard part geometry to identify the maximum angle of the wall during forming. The forming limit and maximum inclination angle of the wall have been searched with frustum of cone studies without cracks. ${ }^{5,9}$ Feed rate, spindle speed, step size, tool diameter, lubrication, tool path and angle of wall are important parameters affecting ISF. ${ }^{10,11}$ The maximum angle of the wall has been investigated with two diameter, step-size and sheet-thickness parameters. This value is determined with the experimental solutions applied for different geometries. ${ }^{12,13}$

Many studies have been conducted related to the forming and mechanisc of various materials with the ISF method. ${ }^{14-17}$ The relation of the roughness on the surface of the material in ISF with the tool radius, step size and inclination angle of its parts has been searched numerically and experimentally. ${ }^{18,19}$

The most common four parameters affecting the strength necessary for forming as desired without any damage during forming are the tool diameter, step size, right of the angle of part wall or wall and sheet metal thickness. Tool diameter has been examined in detail, because it is the contact area that stress is intensified generally. ${ }^{15,20-23}$

Suitable selection of the tool and the lubrication in ISF is essential for the successful forming and a homogeneous surface quality. The effect of the tool and lubrication in steel, aluminum and titanium sheets on the quality of the surface treating was investigated with SEM and the measuring device for surface roughness..$^{24,25}$

The comparison of theoretical calculations and the suitability after forming depends on doing the measurements after the processing accurately. For this purpose, the three-dimensional laser scanning technique has been utilized in measurements. This method is one of the contactless test methods and it has a wide area of usage because it provides economic and reliable measurements. The stages of the measuring process are computerized as three-dimensional point clouds (in STL format) by scanning the samples with laser scanning. The point clouds are saved and combined, pierced, the spaces are filled, filtrated and three dimensional solid models of the samples are obtained. At the end, all the necessary measurements can be made over the solid model in a computer environment and become comparable to the geometries. . $^{3,25,26}$

In this study, the applicability of ISF to AA2024-T3 sheets, process performance and economic advantages have been investigated. The other aim of this study is prioritizing the process parameters in ISF. The samples were formed by changing the tool path, step size and lubrication parameters and the geometrical accuracy and thickness alterations and have been measured by the three-dimensional laser scanning method. The comparison of ISF with the die production method was made for this model and the optimum test parameters were determined.

\section{MATERIALS AND METHODS}

\subsection{Materials}

In the study, AA2024-T3 commercial products in 200 $\mathrm{mm} \times 200 \mathrm{~mm} \times 1 \mathrm{~mm}$ sizes were used. The chemical composition and mechanical properties of the material are given in Tables $\mathbf{1}$ and $2 .^{27}$

Table 1: Chemical composition of AA2024 sample (w/\%)

Tabela 1: Kemijska sestava vzorca AA2024 (w/\%)

\begin{tabular}{|l|c|c|c|c|c|c|c|c|}
\hline Element & $\mathrm{Cu}$ & $\mathrm{Mg}$ & $\mathrm{Mn}$ & $\mathrm{Fe}$ & $\mathrm{Ti}$ & $\mathrm{Zn}$ & $\mathrm{Si}$ & $\mathrm{Al}$ \\
\hline \multirow{2}{*}{ Standard } & $3.80-$ & $1.20-$ & $0.30-$ & $\mathrm{Max}$ & $\mathrm{Max}$ & $\mathrm{Max}$ & $\mathrm{Max}$ & $90.70-$ \\
& 4.90 & 1.80 & 0.90 & 0.50 & 0.15 & 0.25 & 0.50 & 94.70 \\
\hline Measured & 4.59 & 1.49 & 0.54 & 0.10 & 0.02 & 0.02 & 0.07 & 93.14 \\
\hline
\end{tabular}

Table 2: Mechanical properties of AA2024-T3 sample 27

Tabela 2: Mehanske lastnosti vzorca AA2024-T327

\begin{tabular}{|c|c|c|c|}
\hline \multicolumn{2}{|c|}{ Tensile strength (MPa) } & \multicolumn{2}{c|}{ Strain failure (\%) } \\
\hline Standard & Experimental & Standard & Experimental \\
\hline 455 & 480 & 22.80 & 18.75 \\
\hline
\end{tabular}

The experimental data in Tables $\mathbf{1}$ and $\mathbf{2}$ are values in accordance with the standards.

\subsection{Method}

Incremental sheet processes applied to the samples were made with the single-point incremental sheet forming method in a First MCW300 CNC milling stand. The processes were made after the measurement precision of the retainer die specially manufactured for this method was provided and the retainer die was tied to the stand. AA2024-T3 samples which were laser cut in a way to be tied to the die $(200 \times 200 \times 1) \mathrm{mm}$ were anchored with the help of $8 \mathrm{M} 10$ bolts during forming to prevent the sliding.

An uncoated carbide tool with a $10 \mathrm{~mm}$ diameter was chosen for the tool, which is one of the important parameters in forming. The feed rate was kept constant at $1000 \mathrm{~mm} / \mathrm{min}$ and the spindle speed at $500 \mathrm{~min}^{-1}$ in all the tests. The tool path, step size and lubrication parameters were changed in the processes. All the performed parameters in this study are given in Table 3. 

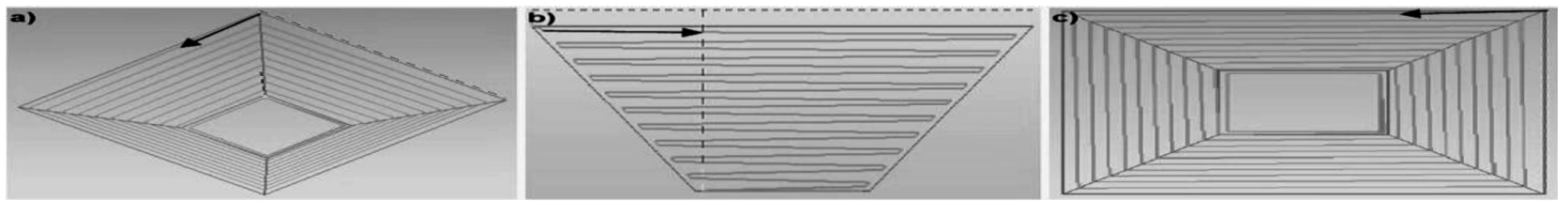

Figure 1: a) Perspective, b) side, c) top view of the tool path numbered 1

Slika 1: a) Perspektiva, b) stranski pogled, c) pogled iz vrha na pot orodja številka 1
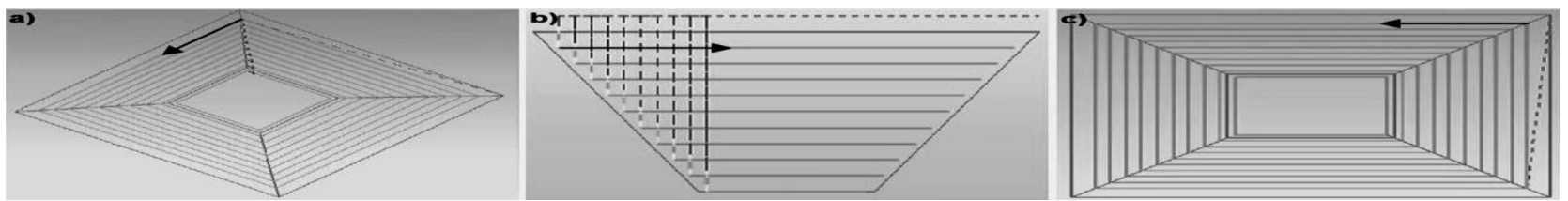

Figure 2: a) Perspective, b) side, c) top view of the tool path numbered 2

Slika 2: a) Perspektiva, b) stranski pogled, c) pogled z vrha na pot orodja številka 2

Table 3: All performed parameters

Tabela 3: Vsi uporabljeni parametri

\begin{tabular}{|c|c|c|c|}
\hline $\begin{array}{l}\text { Number of } \\
\text { experiment }\end{array}$ & $\begin{array}{l}\text { Number of } \\
\text { tool path }\end{array}$ & Step size & Lubrication \\
\hline 1 & \multirow{4}{*}{1} & \multirow{2}{*}{0,2} & A Lubricate \\
\hline 2 & & & B Lubricate \\
\hline 3 & & \multirow{2}{*}{0,5} & A Lubricate \\
\hline 4 & & & B Lubricate \\
\hline 5 & \multirow{4}{*}{2} & \multirow{2}{*}{0,2} & A Lubricate \\
\hline 6 & & & B Lubricate \\
\hline 7 & & \multirow{2}{*}{0,5} & A Lubricate \\
\hline 8 & & & B Lubricate \\
\hline
\end{tabular}

Two different tool paths were designed using the NX Unigraphics CAM program. The first tool path does the step size as spirals and in this process the tool always keeps in contact with the sheet metal. The second one is the tool path always gives the step size from the same point after completing the whole circuit in a horizontal line. The perspective, side and top views of the 1st and 2nd tool paths are given in Figures $\mathbf{1}$ and $\mathbf{2}$ and again doing the same process incrementally. If during this

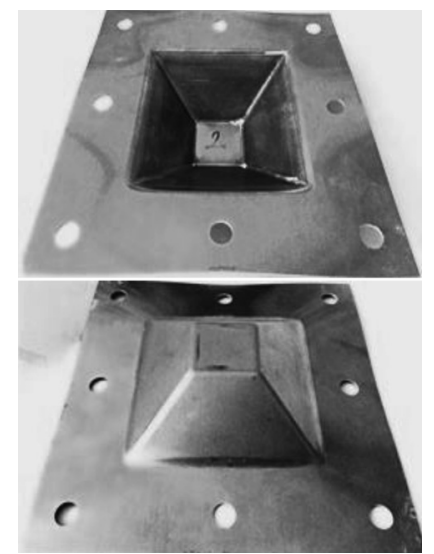

Figure 3: A lubricant, the views of the sample having $0.5 \mathrm{~mm}$ step size and 1st tool path parameters

Slika 3: Mazivo A, izgled vzorca s korakom $0,5 \mathrm{~mm}$ in poti orodja številka 1 process the tool does not contact with the sheet metal continuously. The $0.2 \mathrm{~mm}, 0.3 \mathrm{~mm}, 0.5$ and $0.7 \mathrm{~mm}$ values were tested for step sizes and the $0.2 \mathrm{~mm}$ and 0.5 mm step sizes were chosen.

Two different lube lubricates of which technical properties are given Table 4 were chosen for the lubrication in the application. The first one has been chosen as B lubricate emulsion, which is the machining coolant and the other one as the A lubricant.

Table 4: Technical properties of the used lubricants

Tabela 4: Lastnosti uporabljenih maziv

\begin{tabular}{|l|c|c|}
\hline & A Lubricate & B Lubricate \\
\hline $\begin{array}{l}\text { Kinematic viscosity } \\
\left(40^{\circ} \mathrm{C}, \mathrm{mm}^{2} / \mathrm{s}\right)\end{array}$ & $115-135$ & $25-35$ \\
\hline
\end{tabular}

\section{RESULTS}

Solid models of the samples formed by the parameters determined with the incremental sheet forming were obtained by the method of three-dimensional laser scanning. Geometrical accuracies and thickness distributions of the solid models and the geometries that are

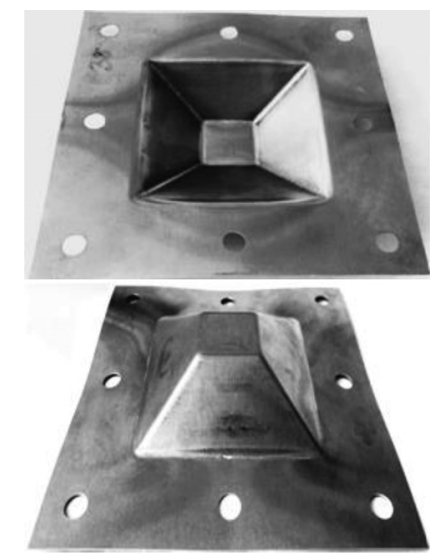

Figure 4: B lubricant, the views of the sample having $0.2 \mathrm{~mm}$ step size and 2nd tool path parameters

Slika 4: Mazivo B, izgled vzorca s korakom $0,2 \mathrm{~mm}$ in poti orodja številka 2 
H. BAYRAM, N. S. KÖKSAL: INVESTIGATION OF THE GEOMETRICAL ACCURACY AND THICKNESS ...

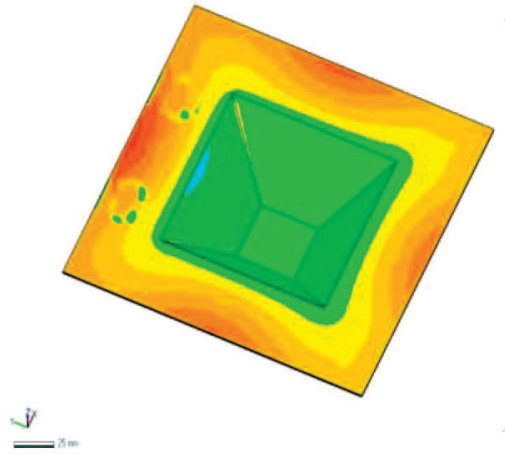

(a)

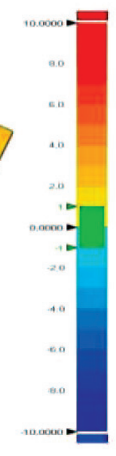

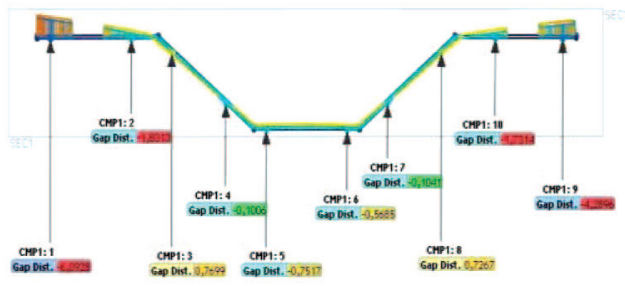

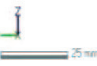

(b)

Figure 5: A lubricant, the results of geometric accuracy of the sample (a, b) having $0.5 \mathrm{~mm}$ step size and 1 st tool path parameters Slika 5: Mazivo A, rezultati geometrijske natančnosti vzorca $(\mathrm{a}, \mathrm{b})$, pri koraku $0,5 \mathrm{~mm}$ in poti orodja številka 1

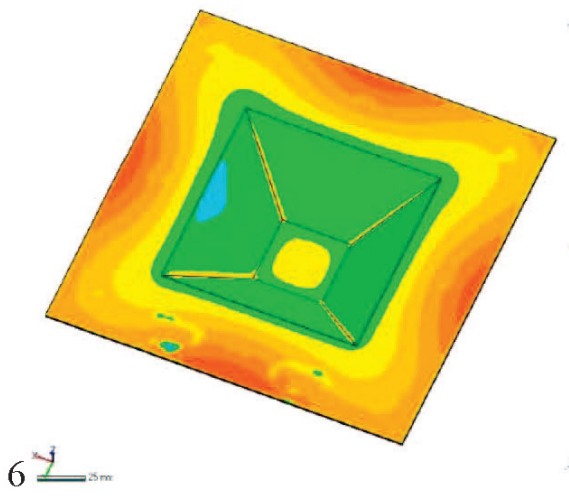

(a)

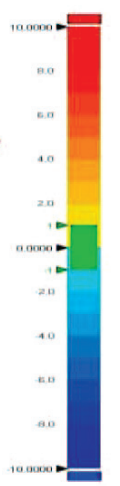

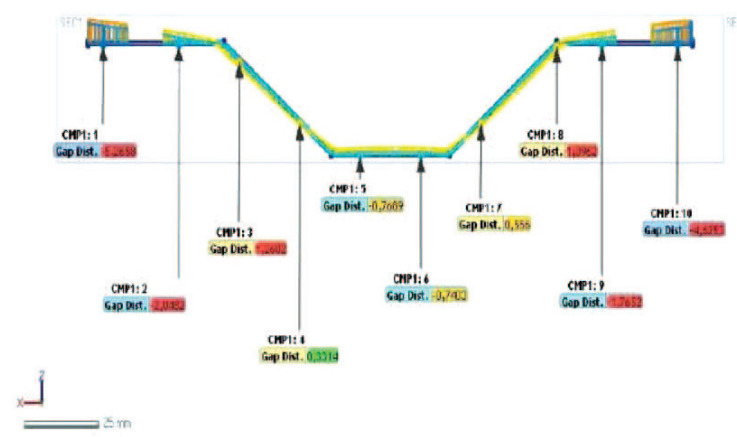

(b)

Figure 6: B lubricant the results of geometric accuracy of the sample (a, b) having $0.2 \mathrm{~mm}$ step size and $2 \mathrm{nd}$ tool path parameters Slika 6: Mazivo B, rezultati geometrijske natančnosti vzorca $(\mathrm{a}, \mathrm{b})$, pri koraku $0,2 \mathrm{~mm}$ in poti orodja številka 2

aimed to give to the samples were compared. Half of the part geometries were taken for the examination because they are symmetrical in this process. The views of the samples obtained after the forming process are given in Figures 3 and 4.

The thickness distribution of the samples after forming have been measured by sectioning the solid models obtained using thr CAD programs.

The values and measurement points of the samples having $0.5 \mathrm{~mm}$ step size and the 1 st tool path parameter

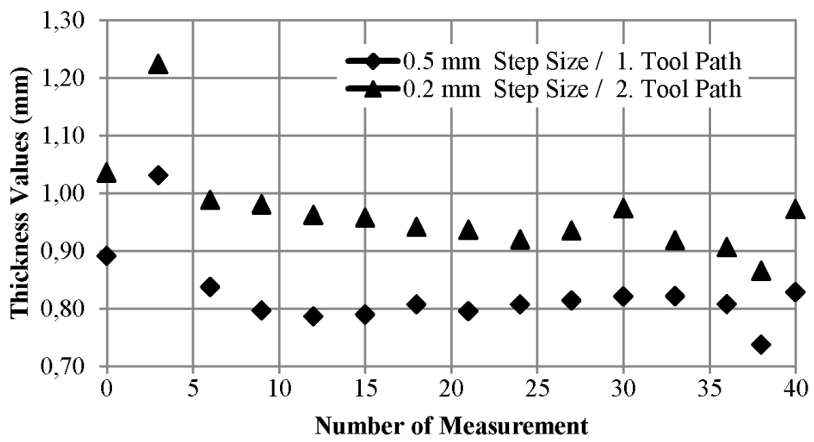

Figure 7: Graph shows measured thickness values of the inclined area $(\mathrm{mm})$

Slika 7: Grafičen prikaz izmerjene debeline na nagnjenem področju (mm)
Table 5: Measured thickness values of the inclined area ( $\mathrm{mm})$

Tabela 5: Izmerjene vrednosti debeline na nagnjenem področju (mm)

\begin{tabular}{|c|c|c|c|c|c|}
\hline $\begin{array}{c}\text { Number } \\
\text { of } \\
\begin{array}{c}\text { measure- } \\
\text { ment }\end{array}\end{array}$ & $\begin{array}{c}0.5 \mathrm{~mm} \\
\text { step size/ } \\
1 . \text { tool } \\
\text { path }\end{array}$ & $\begin{array}{c}0.2 \mathrm{~mm} \\
\text { step size/ } \\
\text { 2. tool } \\
\text { path }\end{array}$ & $\begin{array}{c}\text { Number } \\
\text { of } \\
\text { measure- } \\
\text { ment }\end{array}$ & $\begin{array}{c}0.5 \mathrm{~mm} \\
\text { step size/ } \\
1 . \text { tool } \\
\text { path }\end{array}$ & $\begin{array}{c}0.2 \mathrm{~mm} \\
\text { step size/ } \\
\text { 2. tool } \\
\text { path }\end{array}$ \\
\hline 1 & 0.8912 & 1.0358 & 21 & 0.8004 & 0.9425 \\
\hline 2 & 0.9458 & 1.1493 & 22 & 0.7955 & 0.9370 \\
\hline 3 & 1.0151 & 1.2310 & 23 & 0.8082 & 0.9484 \\
\hline 4 & 1.0309 & 1.2242 & 24 & 0.8091 & 0.9585 \\
\hline 5 & 0.9328 & 1.1046 & 25 & 0.8072 & 0.9198 \\
\hline 6 & 0.8853 & 1.0143 & 26 & 0.8081 & 0.9474 \\
\hline 7 & 0.8373 & 0.9885 & 27 & 0.8129 & 0.9402 \\
\hline 8 & 0.8102 & 0.9704 & 28 & 0.8141 & 0.9351 \\
\hline 9 & 0.8012 & 0.9787 & 29 & 0.8233 & 0.9368 \\
\hline 10 & 0.7961 & 0.9806 & 30 & 0.8238 & 0.9352 \\
\hline 11 & 0.7837 & 0.9598 & 31 & 0.8209 & 0.9742 \\
\hline 12 & 0.7850 & 0.9579 & 32 & 0.8033 & 0.9304 \\
\hline 13 & 0.7860 & 0.9624 & 33 & 0.8192 & 0.9290 \\
\hline 14 & 0.7910 & 0.9540 & 34 & 0.8215 & 0.9181 \\
\hline 15 & 0.7902 & 0.9489 & 35 & 0.8189 & 0.9032 \\
\hline 16 & 0.7894 & 0.9577 & 36 & 0.8160 & 0.8998 \\
\hline 17 & 0.7956 & 0.9558 & 37 & 0.8076 & 0.9064 \\
\hline 18 & 0.7914 & 0.9362 & 38 & 0.7916 & 0.8967 \\
\hline 19 & 0.8070 & 0.9413 & 39 & 0.7371 & 0.8656 \\
\hline 20 & 0.7998 & 0.9417 & 40 & 0.8280 & 0.9723 \\
\hline & & & & & \\
\hline
\end{tabular}


and $0.2 \mathrm{~mm}$ step size and the 2 nd tool path parameter among the samples formed are given in Figures 5 and $\mathbf{6}$. Comparative results of the measurements can be seen in Figure 7.

\section{CONCLUSION}

AA2024 materials formed in an acceptable way without being damaged by using incremental sheet forming. The effective parameters in this process are the lubricating fluid, the step size and the tool path. The type of tool, the feed rate and the number of revolution parameters were kept stable.

The A and B lubricants were used for the lubricating fluid, which is an effective parameter in forming. It was observed in the examination after processing that these two lubricating fluids were successful at the same rate.

Two different tool paths were used in the processes. It is clear that the tool path that is always in contact with the spirals is more successful than the tool path doing the progressive process. When the tool path which follows a spiral path and of which vertical steps enter from different points has been tried, different results could not be obtained. The first tool path has given better results in terms of geometrical accuracy and a homogeneous thickness distribution in the forming products. It was observed that the parameter having $0.5 \mathrm{~mm}$ step size displayed more geometrical accuracy and a more homogeneous distribution than the one with the $0.2 \mathrm{~mm}$ step size.

It was identified that the thickness alteration in the product showed a change suitable to the theoretical calculations by measuring accurately after ISF forming. In the results of the accurate measurement method 3D laser scanning, the alteration in the measured values in the middle of the product has been obtained at an acceptable level. The desired form with this method is the middle part of the sample and its sides need to be removed after the process. Therefore, it is not important that the alteration in the side values after forming is too much.

The economy of the method has been investigated in terms of die cost and labor cost, etc. Accordingly, the incremental sheet forming method is cheaper than the die production for the series of less than 500. However, if the number exceeds this value, the method loses its economic advantage. This method stands out in the private and less numbered productions.

The process has been carried out by applying very small strength compared to deep drawing and free from the size of the product in sheet forming. Correspondingly, it has been seen to stay in the safe area in the forming limit diagram (FLD) during forming.

\section{Acknowledgement}

This work has been carried out with the financial support from Celal Bayar University Scientific Research Projects Commission (2014-078).

\section{REFERENCES}

${ }^{1}$ M. Benisa, B. Babic, A. Grbovic, Z. Stefanovic, Computer-Aided Modeling of the Rubber-Pad Forming Process, Mater. Tehnol., 46 (2012) 5, 503-510

${ }^{2}$ I. Cerro, E. Maidagan, J. Arana, A. Rivero, P. P. Rodriguez, Theoretical and experimental analysis of the dieless incremental sheet forming process, Journal of Materials Processing Technology, 177 (2006) 1, 404-408, doi:10.1016/j.jmatprotec.2006.04.078

${ }^{3}$ G. Ambrogio, L. De Napoli, L. Filice, F. Gagliardi, M. Muzzupappa, Application of Incremental Forming process for high customized medical product manufacturing, Journal of Materials Processing Technology, 162 (2005), 156-162, doi:10.1016/j.jmatprotec.2005. 02.148

${ }^{4}$ G. Centeno, I. Bagudanch, A. J. Martínez-Donaire, M. L. GarcíaRomeu, C. Vallellano, Critical analysis of necking and fracture limit strains and forming forces in single-point incremental forming, Materials \& Design, 63 (2014), 20-29, doi:10.1016/j.matdes. 2014.05.066

${ }^{5}$ G. Hussain, G. Lin, N. Hayat, A new parameter and its effect on the formability in single point incremental forming: a fundamental investigation, Journal of Mechanical Science and Technology, 24 (2010) 8, 1617-1621, doi:10.1007/s12206-010-0514-1

${ }^{6} \mathrm{~K}$. Galanulis, Optical measuring technologies in sheet metal processing, Advanced Materials Research, 6 (2005), 19-34, doi:10.4028/ www.scientific.net/AMR.6-8.19

${ }^{7}$ M. J. Mirnia, B. M. Dariani, H. Vanhove, J. R. Duflou, An investigation into thickness distribution in single point incremental forming using sequential limit analysis, International Journal of Material Forming, 7 (2014) 4, 469-477, doi:10.1007/s12289-013-1143-X

${ }^{8}$ D. H. Nimbalkar, V. M. Nandedkar, Review of incremental forming of sheet metal components, Journal of Engineering Research and Applications, 3 (2013) 5, 39-51

${ }^{9}$ D. Young, J. Jeswiet, Wall thickness variations in single-point incremental forming, Proceedings of the Institution of Mechanical Engineers, Part B: Journal of Engineering Manufacture, 218 (2004) 11, 1453-1459, doi:10.1243/0954405042418400

${ }^{10}$ S. Kurra, S. P. Regalla, Experimental and numerical studies on formability of extra-deep drawing steel in incremental sheet metal forming, Journal of Materials Research and Technology, 3 (2014) 2 , 158-171, doi:10.1016/j.jmrt.2014.03.009

${ }^{11}$ S. B. Echrif, M. Hrairi, Significant parameters for the surface roughness in incremental forming process, Materials and Manufacturing Processes, 29 (2014) 6, 697-703, doi:10.1080/10426914.2014. 901519

${ }^{12}$ R. Malhotra, A. Bhattacharya, A. Kumar, N. V. Reddy, J. Cao, A new methodology for multi-pass single point incremental forming with mixed toolpaths, CIRP Annals-Manufacturing Technology, 60 (2011) 1, 323-326, doi:10.1016/j.cirp.2011.03.145

${ }^{13}$ J. C. LI, L. I. Chong, T. G. Zhou, Thickness distribution and mechanical property of sheet metal incremental forming based on numerical simulation, Transactions of Nonferrous Metals Society of China, 22 (2012), 54-60, doi:10.1016/S1003-6326(12)61683-5

${ }^{14}$ M. S. Shim, J. J. Park, The formability of aluminum sheet in incremental forming, Journal of Materials Processing Technology, 113 (2001) 1, 654-658, doi:10.1007/BF03177368

${ }^{15}$ K. Jackson, J. Allwood, The mechanics of incremental sheet forming, Journal of Materials Processing Technology, 209 (2009) 3, 1158-1174, doi:10.1016/j.jmatprotec.2008.03.025 


\section{MATERIALI IN TEHNOLOGIJE/MATERIALS AND TECHNOLOGY (1967-2017) - 50 LET/50 YEARS}

\section{H. BAYRAM, N. S. KÖKSAL: INVESTIGATION OF THE GEOMETRICAL ACCURACY AND THICKNESS ...}

${ }^{16}$ B. Lu, H. Ou, S. Q. Shi, H. Long, J. Chen, Titanium based cranial reconstruction using incremental sheet forming, International Journal of Material Forming, (2014), 1-10, doi:10.1007/s12289-014-1205-8

${ }^{17}$ J. Park, J. Kim, N. Park, Y. Kim, Study of forming limit for rotational incremental sheet forming of magnesium alloy sheet, Metallurgical and Materials Transactions A, 41 (2010) 1, 97-105, doi:10.1007/ s11661-009-0043-7

${ }^{18}$ M. Durante, A. Formisano, A. Langella, Comparison between analytical and experimental roughness values of components created by incremental forming, Journal of Materials Processing Technology, 210 (2010) 14, 1934-1941, doi:10.1016/j.jmatprotec. 2010.07.006

${ }^{19}$ G. Hussain, L. Gao, N. Hayat, Forming parameters and forming defects in incremental forming of an aluminum sheet: correlation, empirical modeling, and optimization: part A, Materials and Manufacturing Processes, 26 (2011) 12, 1546-1553, doi:10.1080/ 10426914.2011.552017

${ }^{20}$ J. Duflou, Y. Tunckol, A. Szekeres, P. Vanherck, Experimental study on force measurements for single point incremental forming, Journal of Materials Processing Technology, 189 (2007) 1, 65-72, doi:10.1016/j.jmatprotec.2007.01.005

${ }^{21}$ M. Durante, A. Formisano, A. Langella, F. M. C. Minutolo, The influence of tool rotation on an incremental forming process, Journal of Materials Processing Technology, 209 (2009) 9, 4621-4626, doi:10.1016/j.jmatprotec.2008.11.028
${ }^{22}$ P. A. F. Martins, N. Bay, M. Skjødt, M. B. Silva, Theory of single point incremental forming, CIRP Annals-Manufacturing Technology, 57 (2008) 1, 247-252, doi:10.1016/j.cirp.2008.03.047

${ }^{23}$ M. B. Silva, M. Skjødt, P. A. Martins, N. Bay, Revisiting the fundamentals of single point incremental forming by means of membrane analysis, International Journal of Machine Tools and Manufacture, 48 (2008) 1, 73-83, doi:10.1016/j.ijmachtools.2007.07.004

${ }^{24}$ G. Hussain, N. Hayat, L. Gao, An experimental study on the effect of thinning band on the sheet formability in negative incremental forming, International Journal of Machine Tools and Manufacture, 48 (2008) 10, 1170-1178, doi:10.1016/j.jmatprotec.2008. 03.025

${ }^{25}$ J. J. Park, Y. H. Kim, Fundamental studies on the incremental sheet metal forming technique, Journal of Materials Processing Technology, 140 (2003) 1, 447-453, doi:10.1016/S0924-0136(03)00768-4

${ }^{26}$ E. Malyer, The Influence of Toolpath Strategy on Geometric Accuracy in Incremental Forming, Key Engineering Materials, 554 (2013), 1351-1361, doi:/www.scientific.net/KEM.554-557.1351

${ }^{27}$ S. A. Khodir, T. Shibayanagi, M. Naka, Microstructure and mechanical properties of friction stir welded AA2024-T3 aluminum alloy, Materials Transactions, 47 (2006) 1, 185-193, doi:10.2320/ matertrans.47.185 